\title{
Microstructural Features and Mechanical Properties of Artificially Aged AA2024
}

\author{
Naveed Afzal, ${ }^{1}$ Tariq Shah, and R. Ahmad \\ Government College University, Lahore, Pakistan \\ ${ }^{1}$ naveed.phys@gmail.com
}

УдК 539.4

\section{Микроструктурные особенности и механические свойства искусственно состаренного сплава АА2024}

\author{
Навид Афзал, Тарик Шах, Р. Ахмад \\ Правительственный университет, Лахор, Пакистан \\ Исследованы микроструктурные особенности и механические свойства сплава $\mathrm{Al}-\mathrm{Cu}-\mathrm{Mg}$ \\ (АА2024) после старения с разной длительностью при температуре $105 \ldots 195^{\circ} \mathrm{C}$. Одну группу \\ образиов подвергали старению при 105, 135, 165 и $195^{\circ} \mathrm{C}$ в течение 2 ч, другую - при одинако- \\ вой температуре в течение 3,5; 3; 2,5 и 2 ч. Дифракиия рентгеновских лучей и растровая \\ электронная микроскопия свидетельствуют об образовании выделений $S$ - $\left(\mathrm{Al}_{2} \mathrm{CuMg}\right)$ u $\Theta$-фаз \\ $\left(\mathrm{Al}_{2} \mathrm{Cu}\right)$, плотность и размеры которых изменяются вследствие изменения времени и темпе- \\ ратуры старения. Обнаружены аномальные изменения значений пределов текучести и проч- \\ ности при растяжении, пластического удлинения, модуля упругости и твердости при изме- \\ нении температуры или времени старения. Образиы, которые подвергались старению при \\ 135 и $195^{\circ} \mathrm{C}$, имели максимальное значение прочности и твердости, в то время как пластич- \\ ность незначительно уменьшалась по сравнению с таковой образиов, подвергшихся старению \\ с разной длительностью при других температурах.
}

Ключевые слова: искусственное старение, алюминиевые сплавы, выделения, механические свойства.

Introduction. Age hardening in aluminum alloys has been a subject of interest since its discovery in Al-Cu alloys by Alfred Wilm about one hundred years ago [1]. It is considered to be a novel way to increase the strength of the aluminum alloys which are used for aerospace, marine, automotive and other engineering applications. Aluminum alloy 2024 (AA2024) is one such alloy which is often used for these applications and therefore the study of its age hardening has been a prime topic of research. It is well accepted that the microstructure of the aged AA2024 consists of Guinier-Preston-Bagaryatsky (GPB) zones that are formed during the initial stages of the aging treatment and are coherent with the matrix [2-5]. With increase of aging temperature, these transform into the metastable $\mathrm{Al}_{2} \mathrm{CuMg}\left(S^{\prime}\right)$ and $\mathrm{Al}_{2} \mathrm{Cu}\left(\Theta^{\prime}\right)$ precipitates which act as precursors of the equilibrium $S$ and $\Theta$ phase intermetallic particles [6-12]. The structure of $S^{\prime}$ and $\Theta^{\prime}$ has been found similar to $S$ and $\Theta$ precipitates with only a small difference in their lattice parameters $[13,14]$. Various studies were conducted on the understanding of the formation and role of these precipitates on hardness and 
strength of the aged $\mathrm{Al}-\mathrm{Cu}-\mathrm{Mg}$ alloys [15-23]. The literature shows that the hardening of the aged $\mathrm{Al}-\mathrm{Cu}-\mathrm{Mg}$ alloys depends upon the distribution and types of these precipitates in the matrix [15-21]. The formation of $S$-phase precipitates in $\mathrm{Al}-\mathrm{Cu}-\mathrm{Mg}$ alloys during the aging treatment is found to be more useful in increasing the hardness and strength of the alloy than the $\Theta$-phase precipitates [5, 14]. Recently, work has been carried out on the mechanical properties of AA2024 after its artificial aging at different temperatures and time [22-24]. Gurugubelli [22] studied the hardness and impact toughness of $\mathrm{Al}-\mathrm{Cu}-\mathrm{Mg}$ alloy after aging it for different durations $(1-18 \mathrm{~h})$ at $200^{\circ} \mathrm{C}$. The impact toughness of the alloy showed anomalous trend with the aging time and became minimum at the peak hardness value. In another work of Abbas regarding the aging time effects on the hardness of spot welded joints of $\mathrm{Al}-\mathrm{Cu}-\mathrm{Mg}$ alloy [23], it was observed that the hardness of the material becomes maximum it is aged at $190^{\circ} \mathrm{C}$ for 3 and $5 \mathrm{~h}$, respectively. Similarly, Reis et al. [24] studied hardness, tensile and fatigue strength of AA2024 alloy after its artificial aging at 190 and $208^{\circ} \mathrm{C}$ for $2 \mathrm{~h}$. The specimens aged at $208^{\circ} \mathrm{C}$ for $2 \mathrm{~h}$ showed the maximum yield and tensile strength followed by a decrease in its ductility as compared to those aged at $190^{\circ} \mathrm{C}$.

Despite numerous efforts in investigating the precipitation hardening of $\mathrm{Al}-\mathrm{Cu}-\mathrm{Mg}$ alloys, there still exists a considerable amount of interest to find out the optimum aging temperature and the time at which the material shows a good combination of hardness, strength and the ductility because of the anomalies present in its mechanical properties. In the present study, artificial aging of AA2024 specimens has been carried out at temperatures ranging from 105 to $195^{\circ} \mathrm{C}$ for different durations $(2-3.5 \mathrm{~h})$. A systematic correlation has been made between the microstructural features, mechanical properties and fractographs of the aged specimens.

1. Experimental. $\mathrm{Al}-\mathrm{Cu}-\mathrm{Mg}$ alloy (AA2024) used in the present work contains 93.5 wt.\% Al, 4.4 wt.\% Cu, 1.5 wt.\% $\mathrm{Mg}$, and 0.6 wt.\% Mn. The alloy specimens in strip form (with dimensions $30 \times 3.2 \times 6.4 \mathrm{~mm}$ ) were ground using emery papers of different grades followed by their polishing using diamond pastes up to $3 \mu \mathrm{m}$. Two batches each containing five specimens were prepared for the experiment. The samples were given solution heat treatment inside the muffle at $495^{\circ} \mathrm{C}$ for $2 \mathrm{~h}$ and then rapidly quenched in air up to the room temperature. The aging of one set of the specimens was performed at $105,135,165$, and $195^{\circ} \mathrm{C}$ for $2 \mathrm{~h}$ in the furnace whereas in the other set, the specimens were aged at 105, 135, 165 , and $195^{\circ} \mathrm{C}$ for $3.5,3,2.5$, and $2 \mathrm{~h}$, respectively. X-ray diffraction analysis of the solution treated (ST) and the aged specimens was carried out by using the $\mathrm{X}$-ray diffractometer (XRD) operating at $\mathrm{CuK} \alpha$ line with $40 \mathrm{kV}$ and $40 \mathrm{~mA}$ voltage and current, respectively. The secondary electron images of the ST and aged specimens were taken using the scanning electron microscope (SEM). Hardness tests of the ST and aged specimens were conducted using Vickers hardness tester at room temperature. For the tensile testing, specimens with gauge length $30 \mathrm{~mm}$ were inserted inside the jaw faces of the universal testing machine and their stressstrain curves were recorded by the attached software at the room temperature. The fractographs of the deformed specimens were taken using the SEM and a systematic correlation was made between the microstructure and mechanical properties of the material. The experiment was repeated to confirm the obtained results. 


\section{Results.}

2.1. XRD Results. XRD patterns of AA2024 after its aging at 105, 135, 165, and $195^{\circ} \mathrm{C}$ for $2 \mathrm{~h}$ are shown in Fig. 1. The figure shows that in case of the ST sample, the peaks of aluminum solid solution ( $\alpha$-Al) corresponding to (111), (200), (220), and (311) planes appear at 38.3, 44.6, 65, and $78^{\circ}$, respectively. Aging treatment of the material at $105^{\circ} \mathrm{C}$ for $2 \mathrm{~h}$ reveals an additional peak of $\mathrm{Al}_{2} \mathrm{CuMg}$ at $27^{\circ}$ along (111) and $\mathrm{Al}_{2} \mathrm{Cu}\left(\Theta\right.$-phase) peak at $42^{\circ}$ along $(112)$ plane $[25,26]$. By increasing the aging time to $135^{\circ} \mathrm{C}$, the $\alpha$-Al peak at $78^{\circ}$ disappears and the $S$-phase peak pertaining to (206) plane occurs at its place. Moreover, two additional $\Theta$-peaks are also formed at 20.5 and $47^{\circ}$ along (110) and (112) planes, respectively $[27,28]$. With increase of aging temperature to $165^{\circ} \mathrm{C}$, the $\alpha$-Al peak appears again at $78^{\circ}$ whereas the remaining $S$ and $\Theta$ peaks form at the same angles as observed for the specimen aged at $135^{\circ} \mathrm{C}$. At $195^{\circ} \mathrm{C}$, the $\Theta$ peak at $20.5^{\circ}$ vanishes whereas the $S$-phase peak corresponding to (206) appears at $78^{\circ}$ instead of the $\alpha$-Al peak. In addition to the $S$ and $\Theta$ peaks, variations in the intensity of $\alpha$-Al peaks also occur (Fig. 1).

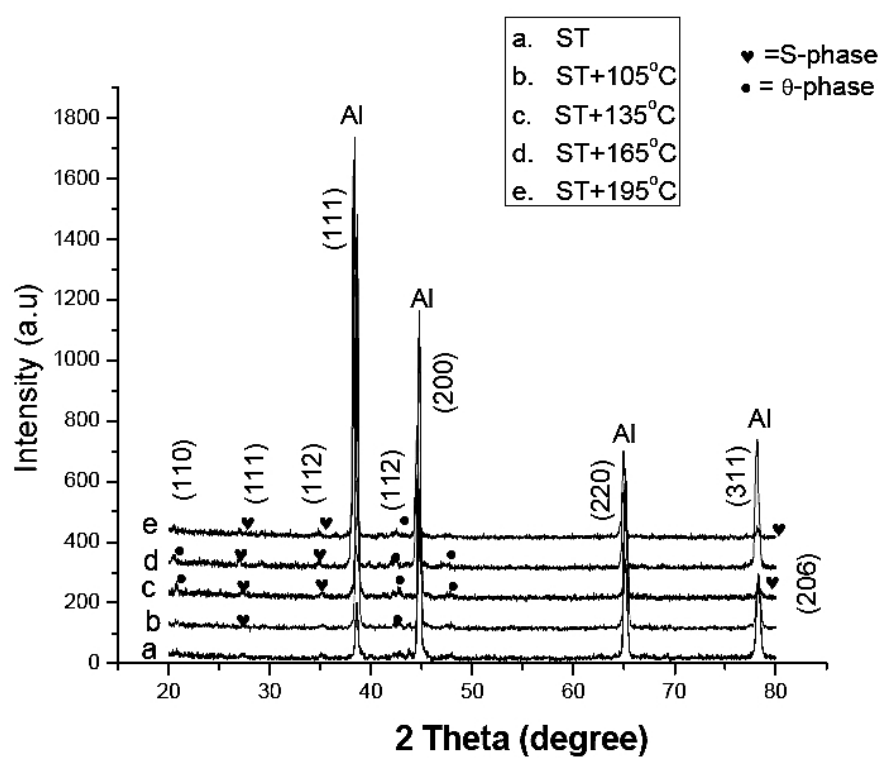

Fig. 1. XRD patterns of AA2024 as function of the aging temperatures.

Figure 2 shows the XRD spectra of AA2024 specimens aged at 105, 135, 165, and $195^{\circ} \mathrm{C}$ for $3.5,3,2.5$, and $2 \mathrm{~h}$, respectively. The results show that $\alpha$-Al peaks are formed at $38.3,44.6,65$, and $78^{\circ}$ corresponding to (111), (200), (220), and (311) planes, respectively, whereas the $S$ and $\Theta$ peaks appear at 35 and $42^{\circ}$ along (112) planes. The comparison of these results with the XRD results of the specimens aged for $2 \mathrm{~h}$ at these temperatures reveals that the $S$-peak at $27^{\circ}$ along (111) and $\Theta$ peak along (110) at $20.5^{\circ}$ disappear (Fig. 2).

2.2. Microstructural Results. Figure 3a-e represents SEM micrographs of the ST and AA2024 specimens aged between $105-195^{\circ} \mathrm{C}$ for $2 \mathrm{~h}$. As seen from Fig. 3a, the microstructure of ST sample consists of solid solution of aluminum $(\alpha-\mathrm{Al})$ along with small inclusions/particles. From Fig. 3b, it is observed that aging of the 


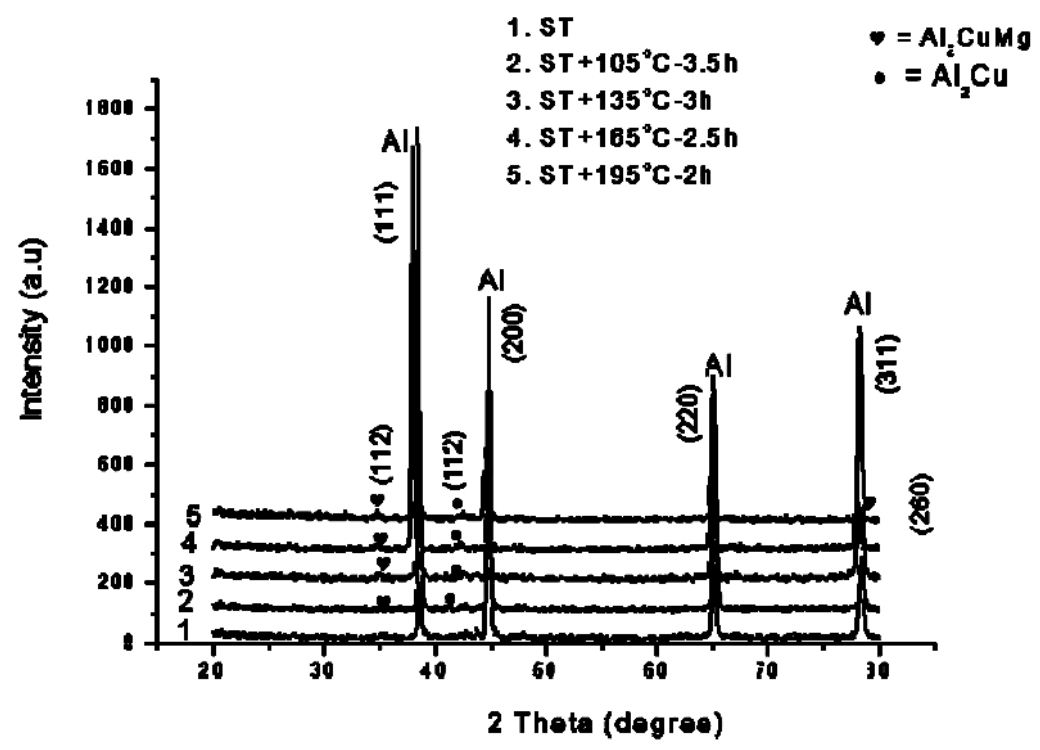

Fig. 2. XRD patterns of AA2024 as function of the aging temperatures and time.

specimen at $105^{\circ} \mathrm{C}$ for $2 \mathrm{~h}$ produces a large number of fine white and dark gray particles/precipitates which may correspond to $S$ and $\Theta$ phases, respectively [29-31]. At few places within the matrix, clustering of precipitates particles can also be observed. With increasing the aging temperature to $135^{\circ} \mathrm{C}$, the number density and size of these particles are found to increase (Fig. 3c). At $165^{\circ} \mathrm{C}$, it is found that a large number of particles/precipitates which were observed at 105 and $135^{\circ} \mathrm{C}$ are dissolved into the parent matrix (Fig. 3d). As a result, a large portion of the matrix becomes free from the precipitates and these regions are termed as precipitate free zones (PFZ). The formation of PFZs in the aluminum matrix indicates a heterogeneous segregation of the precipitates particles around the grain boundaries. The appearance of $\alpha$-Al peak instead of $S$-phase peak at $78^{\circ}$ in the XRD pattern of the specimen aged at $165^{\circ} \mathrm{C}$ supports the dissolution of the precipitates inside the matrix (Fig. 1). The SEM micrograph of AA2024 specimens aged at $195^{\circ} \mathrm{C}$ for $2 \mathrm{~h}$ also indicates the formation of white and dark shaped particles which take the form of clusters at the grain boundaries (Fig. 3e). From the figure, it is further noticed that the density and size of the particles/precipitates formed as a result of aging varies throughout the matrix. The increased density of these precipitate particles at $195^{\circ} \mathrm{C}$ can also be related to the formation of additional $S$-phase peak at $78^{\circ}$ in the XRD spectrum (Fig. 1). Figure $4 a-c$ shows the SEM micrographs of AA2024 specimens aged at $105,135^{\circ} \mathrm{C}$ and for $3.5,3$, and $2.5 \mathrm{~h}$, respectively. From Fig. $4 \mathrm{a}$, it is seen that the size of precipitates/particles formed is significantly increased by aging the specimen at $105^{\circ} \mathrm{C}$ for $3.5 \mathrm{~h}$ as compared to $2 \mathrm{~h}$ at the same temperature. Aging of specimen at $135^{\circ} \mathrm{C}$ for $3 \mathrm{~h}$ displays a similar pattern of large and small size precipitates/particles along with their clusters in the whole matrix. By comparing it with the specimen aged at $135^{\circ} \mathrm{C}$ for $2 \mathrm{~h}$ (Fig. 3c), it is observed that the precipitates coarsen with increase of the aging time from 2 to $3 \mathrm{~h}$ at $135^{\circ} \mathrm{C}$ (Fig. 4b). From Fig. 4c, it is clear that the 


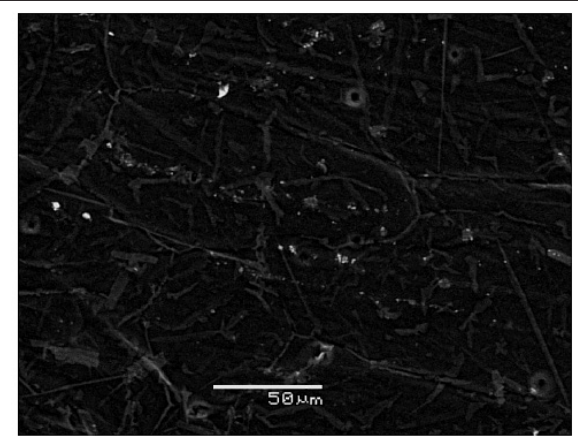

a

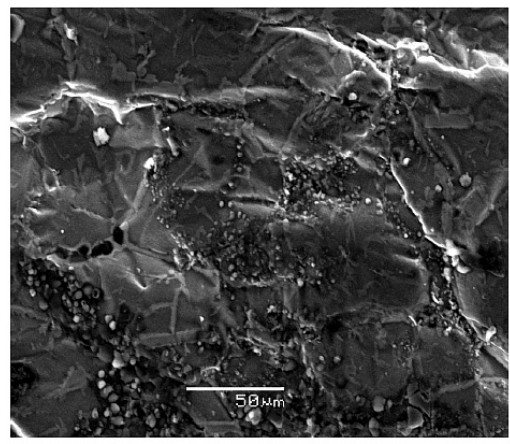

C

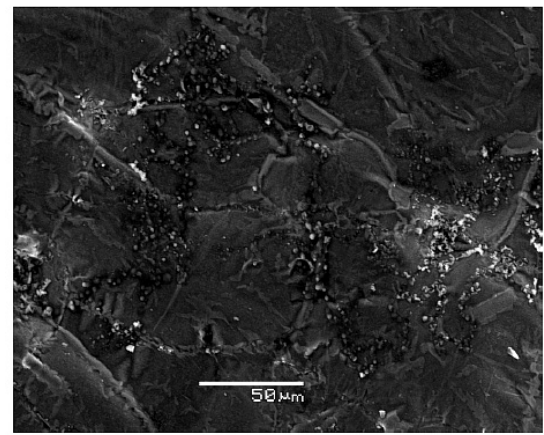

$\mathrm{b}$

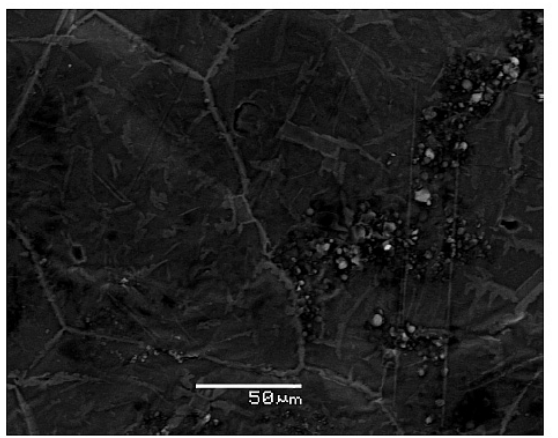

d

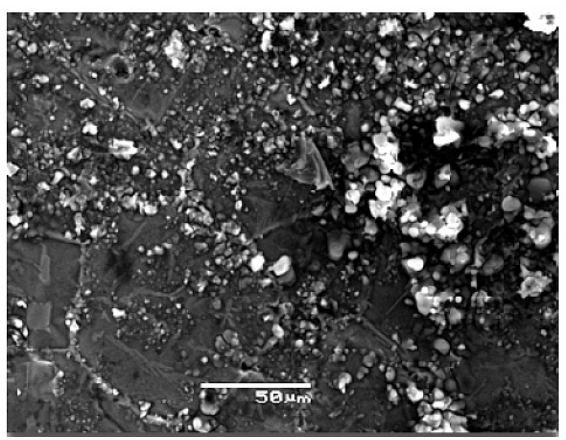

e

Fig. 3. Comparison of microstructures of AA2024 specimens aged at different temperatures for 2 h: (a) solution treated; (b) $105^{\circ} \mathrm{C}$; (c) $135^{\circ} \mathrm{C}$; (d) $165^{\circ} \mathrm{C}$; (e) $195^{\circ} \mathrm{C}$.

aging behavior of AA2024 at $165^{\circ} \mathrm{C}$ for $2.5 \mathrm{~h}$ is the same as that was noted at the same temperature after aging the specimen for $2 \mathrm{~h}$ with a difference that the size of the precipitates/particles has significantly increased after aging at $165^{\circ} \mathrm{C}$ for $2.5 \mathrm{~h}$ (Fig. 4c).

2.3. Hardness Results. The results of Vickers hardness tests are shown in Figs. 5 and 6, respectively. Figure 5 represents a variation in the hardness of AA2024 specimens after aging at different temperatures for $2 \mathrm{~h}$. The hardness increases with increase of the aging temperature from 105 to $135^{\circ} \mathrm{C}$, then decreases at $165^{\circ} \mathrm{C}$ and again starts increasing when aging temperature is increased to $195^{\circ} \mathrm{C}$. Figure 6 shows the hardness results of AA2024 specimens aged at 105, 135, 165, and $195^{\circ} \mathrm{C}$ for $3.5,3,2.5$, and $2 \mathrm{~h}$, respectively. It can be observed that there is an 


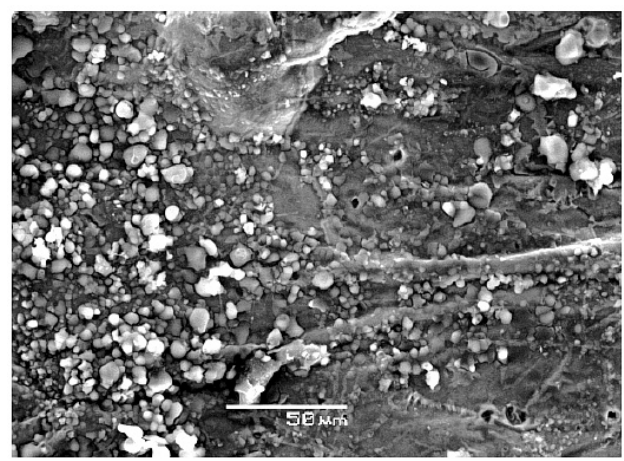

a

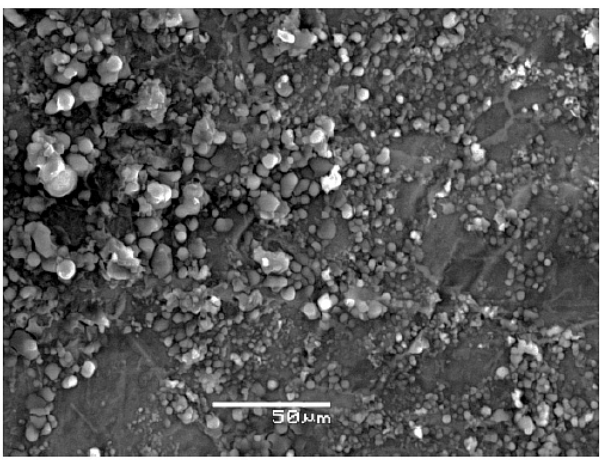

b

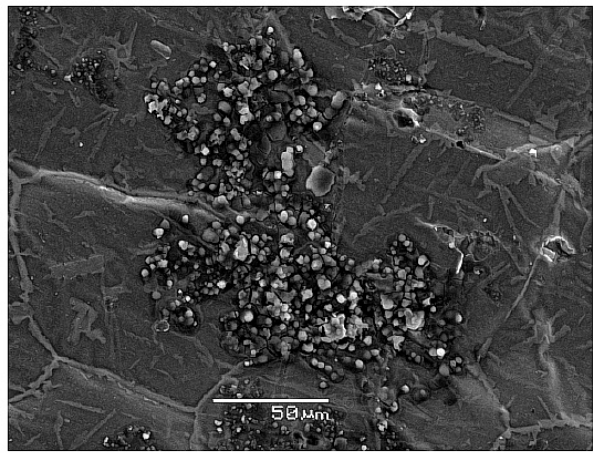

$\mathrm{c}$

Fig. 4. Comparison of microstructures of AA2024 specimens aged at different temperatures for different durations: (a) $105^{\circ} \mathrm{C}-3.5 \mathrm{~h}$; (b) $135^{\circ} \mathrm{C}-3 \mathrm{~h}$; (c) $165^{\circ} \mathrm{C}-2.5 \mathrm{~h}$.

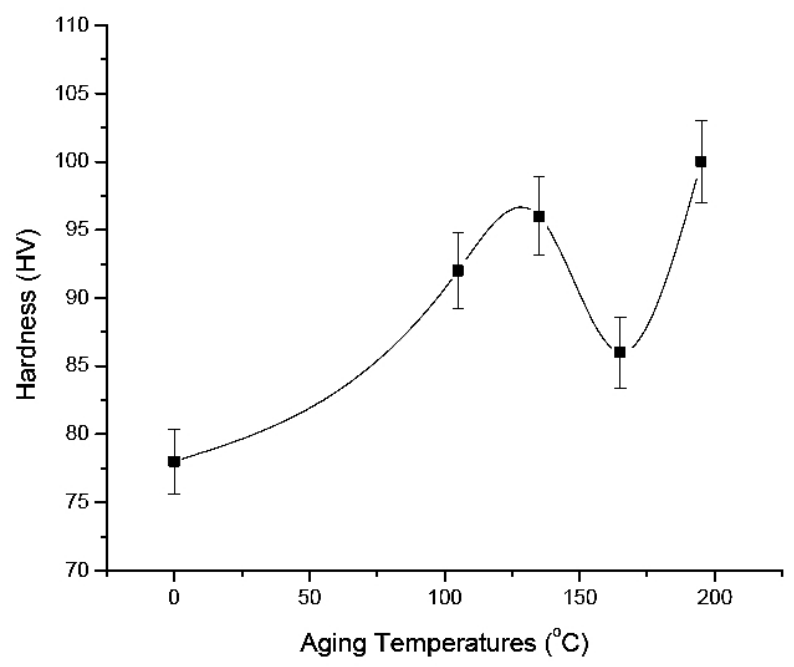

Fig. 5. Variations of hardness with aging temperatures.

increase in the hardness of the specimens aged at 105 and $135^{\circ} \mathrm{C}$ for 3.5 and $3 \mathrm{~h}$, respectively. However, aging of specimen at $165^{\circ} \mathrm{C}$ for $2.5 \mathrm{~h}$ decreases its hardness and upon further increasing the aging temperature to $195^{\circ} \mathrm{C}$ and decreasing the aging time from 2.5 to $2 \mathrm{~h}$, the hardness again increases. 


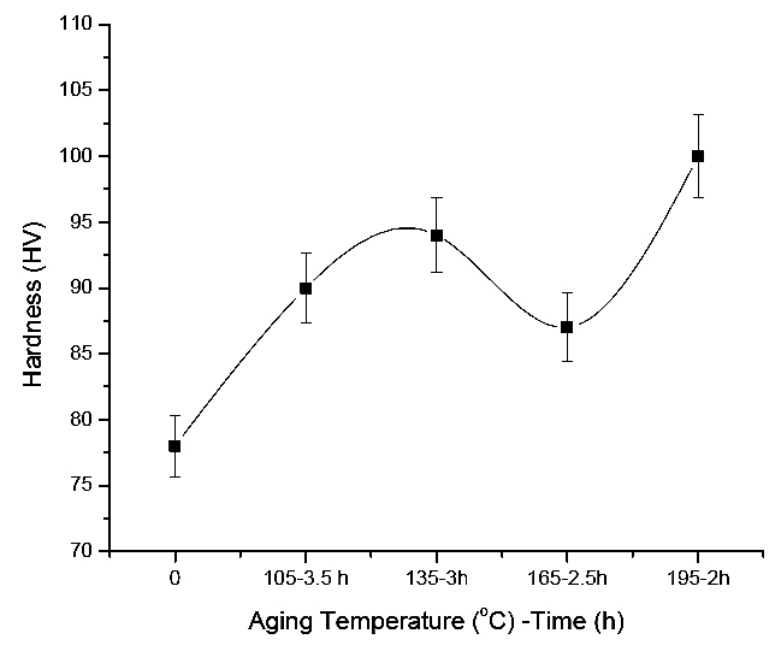

Fig. 6. Variations of hardness with aging time and temperatures.

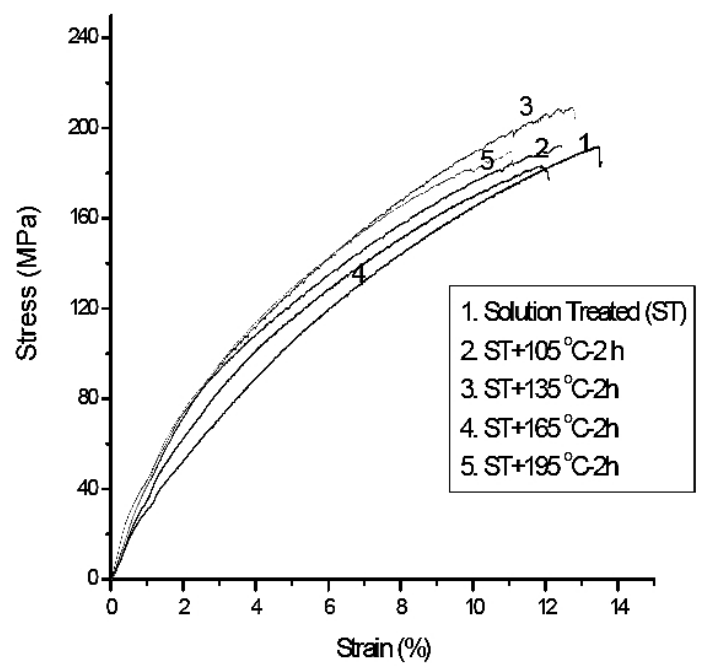

Fig. 7. Stress-strain curves of AA2024 as function of the aging temperatures.

2.4. Tensile Tests Results. Figure 7 displays a comparison of tensile stressstrain curves of ST specimen and the specimens aged at $105-195^{\circ} \mathrm{C}$ for $2 \mathrm{~h}$. The yield strength (YS) and ultimate tensile strength (UTS) increase whereas the plasticity slightly decreases with increase of aging temperature from 105 to $135^{\circ} \mathrm{C}$. When the aging temperature is increased to $165^{\circ} \mathrm{C}$, the YS, UTS, and plasticity are decreased. Upon further increasing the temperature to $195^{\circ} \mathrm{C}$, YS and UTS again increase whereas the plasticity is considerably reduced. It can also be noted that the elastic modulus also changes with change in the aging temperatures. Similarly, Fig. 8 compares the tensile stress-strain curves of AA2024 before aging and after aging at $105,135,165$, and $195^{\circ} \mathrm{C}$ for $3.5,3,2.5$, and $2 \mathrm{~h}$, respectively. Again an anomalous trend in the tensile behavior of AA2024 is observed after changing the aging temperatures and time simultaneously. When the specimens are given the aging treatment at $105^{\circ} \mathrm{C}$ for $3.5 \mathrm{~h}$, its YS, UTS decrease, however, its plasticity 


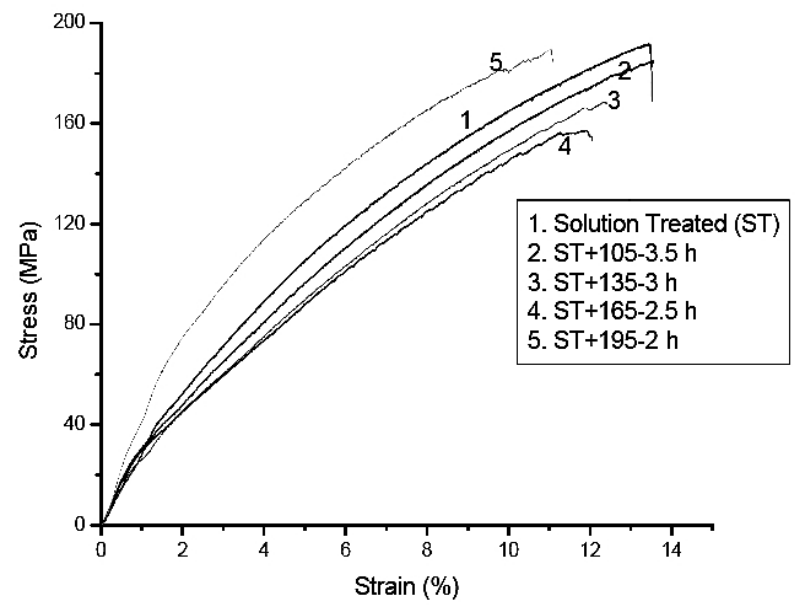

Fig. 8. Stress-strain curves of AA2024 as function of both aging time and temperatures.

remains same. By aging the specimen at $135^{\circ} \mathrm{C}$ for $3 \mathrm{~h}$, the YS, UTS, and plasticity are further decreased. This decrease becomes more pronounced when the aging temperature is set at $165^{\circ} \mathrm{C}$ for $2.5 \mathrm{~h}$. When the aging temperature is increased to $195^{\circ} \mathrm{C}$ for $2 \mathrm{~h}$, the YS and UTS again increase substantially accompanied by a decrease in the plasticity of the material.

2.5. Fractographs Analysis. The fractographs results of AA2024 specimens with respect to different aging temperatures are shown in Fig. 9a-e. The fractured surface of ST shows a large number of dimples which represent a ductile fracture (Fig. 9a). Aging at $105^{\circ} \mathrm{C}$ for $2 \mathrm{~h}$ produces shallow voids inside the dimples and cracks propagation takes place at the grain boundaries which increases the materials' strength and decreases its plasticity (Fig. 9b). With increase of the aging temperature to $135^{\circ} \mathrm{C}$, the fractured surface shows the ductile dimples and cracking around the precipitates (Fig. 9c). However, merging of a few cracks produces relatively flat dimples which results in an increase in the YS and UTS of the material. Aging the material at $165^{\circ} \mathrm{C}$ for $2 \mathrm{~h}$ again produces dimples and cracks especially at the grain boundaries (Fig. 9d). When aging temperature is increased to $195^{\circ} \mathrm{C}$, the flatness of dimples and cracking at the grain boundaries around the precipitates becomes more prominent (Fig. 9e). The flatness of dimples indicates a moderately ductile fracture which results in an increase in YS and UTS of the material as indicated by the stress-strain curve (Fig. 7). Figure 10a shows that aging of AA2024 at $105^{\circ} \mathrm{C}$ for $3.5 \mathrm{~h}$ produces relatively more flat dimples along with the intergranular cracks. By aging the specimen at $135^{\circ} \mathrm{C}$ for $3 \mathrm{~h}$, the intergranular cracking becomes more pronounced (Fig. 10b). When aging is carried out at $165^{\circ} \mathrm{C}$ for $2.5 \mathrm{~h}$, the surface again shows dimples and cracks propagation at the grain boundaries (Fig. 10c). The comparison of Fig. 10a-c with Fig. 9a-e shows that the intergranular cracking and flatness of the dimples become more prominent when the material is aged at 105,135 , and $165^{\circ} \mathrm{C}$ for $3.5,3$, and $2.5 \mathrm{~h}$, respectively, as compared to the other aging temperatures and time.

3. Discussion. The anomalous changes in the mechanical properties of AA2024 after artificial aging at different temperatures and time are attributed to the variations in the number density and size of the $S$ and $\Theta$ phase precipitates. 


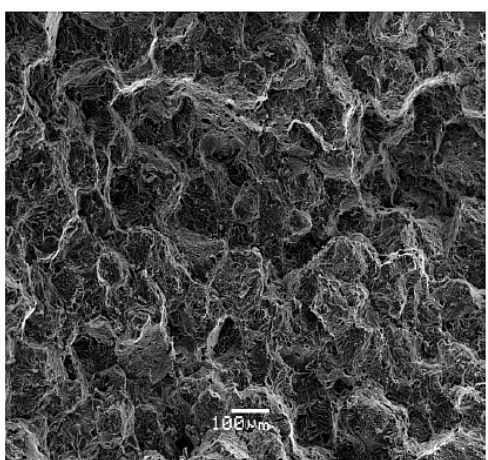

a

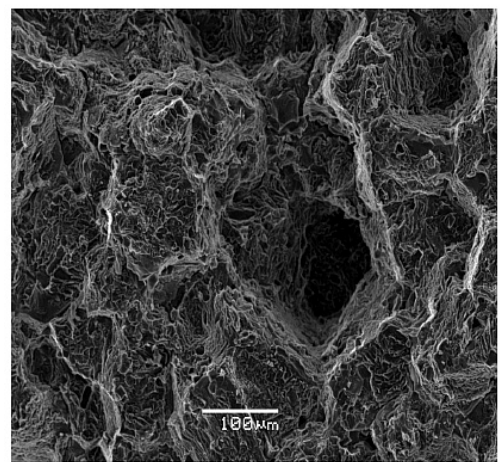

C

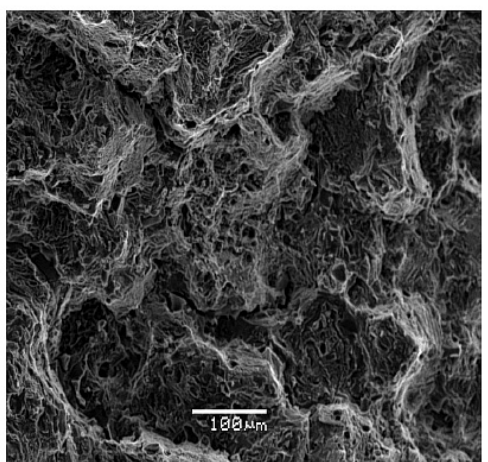

b

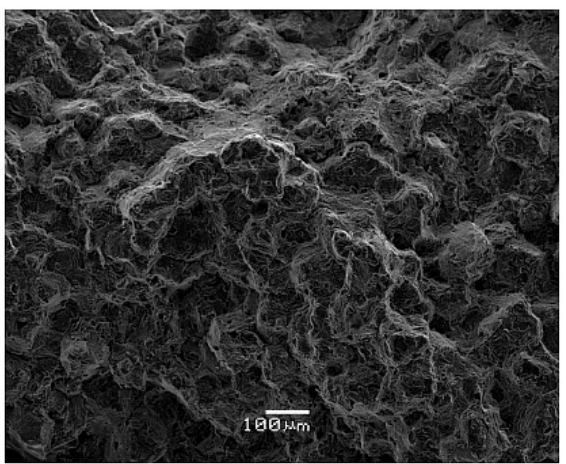

d

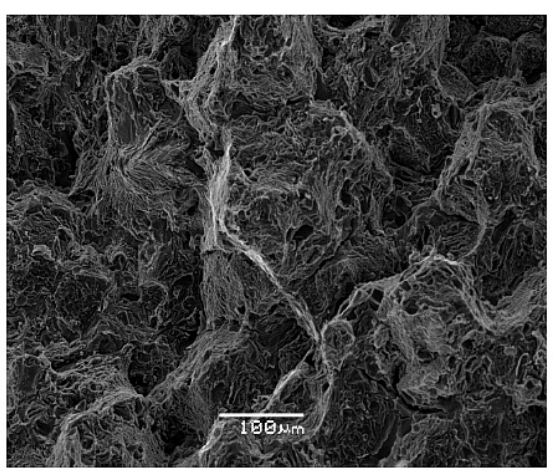

e

Fig. 9. Fractographs of AA2024 specimens aged at different temperatures for $2 \mathrm{~h}$ : (a) solution treated; (b) $105^{\circ} \mathrm{C}$; (c) $135^{\circ} \mathrm{C}$; (d) $165^{\circ} \mathrm{C}$; (e) $195^{\circ} \mathrm{C}$.

When the solution treated sample is aged at $105^{\circ} \mathrm{C}$, then the fine $S$ and $\Theta$ precipitates are formed in it as revealed through the XRD analysis of the specimen (Fig. 1). The formation of these precipitates and their clusters induces local stresses in their vicinity [22], thus causing an increase in the hardness of the alloy. During deformation, the dislocations motion is greatly impeded by these precipitates which results in an increase of the YS, UTS, and FS of the material. An increase in the number of $S$ and $\Theta$ peaks in the XRD spectra of the specimen aged at $135^{\circ} \mathrm{C}$ thus indicates an increase in the number density of these precipitates (Fig. 1). Due to the changes in the density of $S$ and $\Theta$ precipitates, stress variations around 


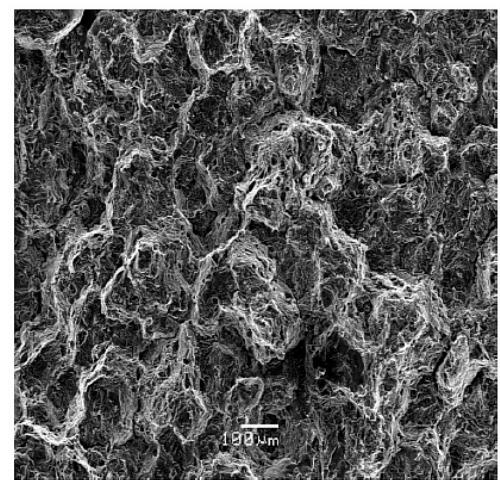

a

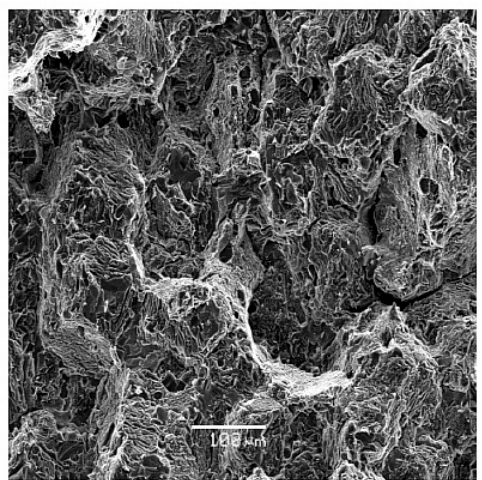

$\mathrm{b}$

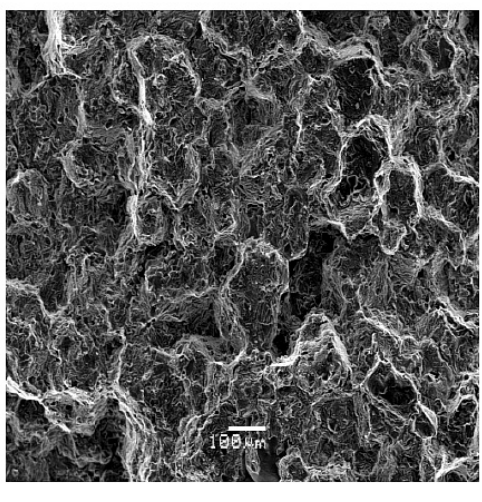

$\mathrm{c}$

Fig. 10. Fractographs of AA2024 specimens aged at different temperatures and time: (a) $105^{\circ} \mathrm{C}-3.5 \mathrm{~h}$; (b) $135^{\circ} \mathrm{C}-3 \mathrm{~h} ;$ (c) $165^{\circ} \mathrm{C}-2.5 \mathrm{~h}$.

them take place which further increase their hardness and the strength. The decrease of hardness and strength of AA2024 aged at $165^{\circ} \mathrm{C}$ for $2 \mathrm{~h}$ is attributed to the dissolution of most of the precipitates inside the parent matrix and as a result PFZs are formed inside the grains (Fig. 9d). Although the clustering of precipitates/particles occurs at few portions in the matrix along the grain boundaries, yet this does not significantly affect the strength and hardness of the material. Instead, it reduces the plastic elongation due to intergranular cracking caused by these precipitates (Fig. 9d). With increase of aging time at $105^{\circ} \mathrm{C}$ from 2 to $3.5 \mathrm{~h}$, the size of precipitates/particles is considerably increased. As the resistance offered by the coarser precipitates to dislocations motion is not as effective as offered by the fine small size precipitates, therefore the YS and UTS of the material decrease when it is aged at $135^{\circ} \mathrm{C}$ for $3.5 \mathrm{~h}$ instead of $3 \mathrm{~h}$. The more pronounced decrease in YS, UTS, and FS of AA2024 sample aged at $165^{\circ} \mathrm{C}$ for $2.5 \mathrm{~h}$ as compared to $2 \mathrm{~h}$ is related to the reduction and coarsening of the precipitates. However, due to decrease in the number density of the precipitates at $2.5 \mathrm{~h}$ aging time, the material's hardness shows a decreasing trend. The specimens aged at 135 and $195^{\circ} \mathrm{C}$ for $2 \mathrm{~h}$ show maximum hardness, YS and UTS along with a decrease in their ductility. This is because of the fact that aging at 135 and $195^{\circ} \mathrm{C}$ for $2 \mathrm{~h}$ significantly increases the density of the $S$ phase precipitates instead of the $\Theta$ phase precipitates which is evident from the XRD analysis of the specimens 
where an additional $S$-phase peak occurs at $78^{\circ}$ and the $\Theta$ peak at $20.5^{\circ}$ vanishes (Fig. 1). Since the presence of $S$-phase precipitates is more effective in restricting dislocation motion as compared to the $\Theta$ precipitates, therefore the strength and hardness of AA2024 increases considerably when it is aged at 135 and $195^{\circ} \mathrm{C}$ for $2 \mathrm{~h}$ as compared to the other aging time and temperatures used in the present work. However, the more prominent decrease in the plasticity of the specimen at $195^{\circ} \mathrm{C}$ as compared to $135^{\circ} \mathrm{C}$ may be due to the more pronounced intergranular cracking caused by the coarser precipitates as observed using the fractograph analysis (Fig. 9).

\section{Conclusions}

1. Artificial aging of AA2024 at $105,135,165$, and $195^{\circ} \mathrm{C}$ for $2 \mathrm{~h}$ produces anomalous variations in its hardness, YS, UTS, elastic modulus, and the plastic elongation. The specimens aged at 135 and $195^{\circ} \mathrm{C}$ for $2 \mathrm{~h}$ exhibit maximum strength and hardness whereas aging at $165^{\circ} \mathrm{C}$ for $2 \mathrm{~h}$ decreases the strength and hardness of the alloy.

2. The increase of hardness and strength at 135 and $195^{\circ} \mathrm{C}$ after $2 \mathrm{~h}$ aging is attributed to an increase in the number of $S$-phase precipitates as compared to the $\Theta$ phase precipitates. The more prominent decrease in the plasticity at $195^{\circ} \mathrm{C}$ compared to $135^{\circ} \mathrm{C}$ is ascribed to more pronounced intergranular cracking caused by relatively coarser precipitates at $195^{\circ} \mathrm{C}$. However, dissolution of the precipitates in the parent matrix at $165^{\circ} \mathrm{C}$ decreases both strength and the hardness of the alloy.

3. Aging of AA2024 at 105,135 , and $165^{\circ} \mathrm{C}$ for $3.5,3$, and $2.5 \mathrm{~h}$, respectively, decreases the YS, UTS, and plastic elongation of the alloy which is related to the coarsening of the $S$ and $\Theta$ precipitates. The increased hardness of the material aged at 105 and $135^{\circ} \mathrm{C}$ for 3.5 and $3 \mathrm{~h}$, respectively, is ascribed to an increase in the density of coarse precipitates.

4. Coarsening of the precipitates promotes intergranular fracture which decreases the plasticity of the material.

Acknowledgements. Mr. Rana M. Ayub and Mr. Sajjad Ahmad are acknowledged for their help during the experimental work.

\section{Резиме}

Досліджено мікроструктурні особливості і механічні властивості сплаву Al$\mathrm{Cu}-\mathrm{Mg}$ (АА2024) після старіння різної тривалості за температури $105 \ldots 195^{\circ} \mathrm{C}$. Одну групу зразків піддавали старінню за $105,135,165$, та $195^{\circ} \mathrm{C}$ протягом 2 годин, іншу - за однакової температури протягом 3,5; 3; 2,5 і 2 годин. Дифракція рентгеновських променів і растрова електронна мікроскопія свідчать про появу виділень $S-\left(\mathrm{Al}_{2} \mathrm{CuMg}\right)$ і $\Theta$-фаз $\left(\mathrm{Al}_{2} \mathrm{Cu}\right)$, густина і розміри яких змінюються внаслідок зміни часу і температури старіння. Виявлено аномальні зміни значень границь текучості і міцності при розтязі, пластичного видовження, модуля пружності і твердості при зміні температури або часу старіння. Зразки, які піддавали старінню при 135 i $195^{\circ} \mathrm{C}$, мали максимальні значення міцності і твердості, в той час як пластичність зменшувалась незначно порівняно зі зразками, що піддавали старінню різної тривалості за інших температур. 
1. A. Wilm, "Physikalisch-metallurgische Untersuchungen über magnesiumhaltige Aluminiumlegierungen," Metallurgie, 8, 225-227 (1911).

2. A. Guinier, "Structure of age-hardened aluminium-copper alloys," Nature, 142, 569-570 (1938).

3. G. D. Preston, "Structure of age-hardened aluminium-copper alloys," Nature, 142, 570 (1938).

4. Y. A. Bagaryatsky, "Structural changes on aging $\mathrm{Al}-\mathrm{Cu}-\mathrm{Mg}$ alloys," Dokl. AN SSSR, 87, 397-401 (1952).

5. J. M. Silcock, "The structural ageing characteristics of $\mathrm{Al}-\mathrm{Cu}-\mathrm{Mg}$ alloys with copper:magnesium weight ratios 7:1 and 2.2:1," J. Inst. Met., 89, 203-210 (1960-61).

6. H. Perlitz and A. Westgren, "The crystal structure of AlCuMg," Ark. Kemi. Mineral. Geol., 16B, 1-5 (1943).

7. L. F. Mondolfo, Aluminum Alloys: Structure and Properties, Butterworths, London (1976).

8. A. K. Gupta, P. Gaunt, and M. C. Chaturvedi, "The crystallography and morphology of the $S^{\prime}$-phase precipitate in an $\mathrm{Al}(\mathrm{CuMg})$ alloy," Phil. Mag. A, 55, 375-387 (1987).

9. S. P. Ringer, K. Hono, I. J. Polmear, and T. Sakurai, "Precipitation processes during the early stages of ageing in Al-Cu-Mg alloys," Appl. Surf. Sci., 94/95, 253-260 (1996).

10. R. Kilaas and V. Radmilovic, "Structure determination and structure refinement of $\mathrm{Al}_{2} \mathrm{CuMg}$ precipitates by quantitative high-resolution electron microscopy," Ultramicroscopy, 88, No. 1, 63-72 (2001).

11. C. Genevois, A. Deschamps, A. Denquin, and B. Doisneau-cottignies, "Quantitative investigation of precipitation and mechanical behaviour for AA2024 friction stir welds," Acta Mater., 53, No. 8, 2447-2458 (2005).

12. S. Abis, M. Massazza, P. Mengucci, and G. Riontino, "Early ageing mechanisms in a high-copper AlCuMg alloy," Scr. Mater., 45, No. 6, 685691 (2001).

13. H.-C. Shih, N. J. Ho, and J. C. Huang, "Kinetic study of precipitation behavior in $\mathrm{Al}-\mathrm{Cu}-\mathrm{Mg}$ and 2024 aluminum alloys," Metall. Mater. Trans., 27A, 2479-2494 (1996).

14. S. C. Wang and M. J. Starink, "Review of precipitation in $\mathrm{Al}-\mathrm{Cu}-\mathrm{Mg}(\mathrm{Li})$ alloys," Int. Mater. Rev., 50, 193-215 (2005).

15. V. Radmilovic, R. Kilaas, U. Dahmen, and G. J. Shiflet, "Structure and morphology of S-phase precipitates in aluminum," Acta Mater., 47, 39873997 (1999).

16. Z. Feng, Y. Yang, B. Huang, et al., "Precipitation process along dislocations in $\mathrm{Al}-\mathrm{Cu}-\mathrm{Mg}$ alloy during artificial aging," Mater. Sci. Eng. A, 528, Issue 2, 706-714 (2010).

17. T. S. Parel, S. C. Wang, and M. J. Starink, "Hardening of an Al-Cu-Mg alloy containing type I and II S phase precipitates," Mater. Des., 31, S2-S5 (2010). 
18. N. Afify, A. Gaber, A. M. Abousehly, and Y. M. Abou Deif, "Precipitation kinetics in supersaturated Al-2.0 at $\% \mathrm{Cu}-1.0$ at\% Mg alloy," Mater. Trans., 51, No. 2, 317-320 (2010).

19. S. C. Wang, M. J. Starink, and N. Gao, "Precipitation hardening in $\mathrm{Al}-\mathrm{Cu}-$ Mg alloys," Scr. Mater., 54, 287-291 (2006).

20. S. C. Wang and M. J. Starink, "Two types of S phase precipitates in Al-Cu-Mg alloys," Acta Mater., 55, No. 3, 933-941 (2007).

21. J. M. Palmerin, Héctor J. Dorantes Rosales, Victor M. López Hirata, et al., "Hardening behavior in aged $\mathrm{Al}-4 \% \mathrm{Cu}-0.3 \% \mathrm{Mg}$ alloys with 0.5 and $2 \% \mathrm{Ag}$ additions," Mater. Trans., 50, No. 12, 2785-2789 (2009).

22. S. N. Gurugubelli, "The effect of ageing on impact toughness and microstructure of 2024 Al-Cu-Mg alloy," World Acad. Sci., Eng. Technol., 62, 648-650 (2012).

23. M. K. Abbass, "Effect of aging time on the mechanical properties of friction stir spot welding of Al-alloy (AA2024)," Int. J. Eng. Res. Appl., 2, 1366-1374 (2012).

24. D. A. P. Reis, A. A. Couto, N. I. Domingues, Jr., et al., "Effect of artificial aging on the mechanical properties of an aerospace aluminum alloy 2024," Defect Diff. Forum, 326-328, 193-198 (2012).

25. J. F. Li, Z. Ziqiao, J. Na, and T. Chengyu, "Localized corrosion mechanism of 2xxx-series $\mathrm{Al}$ alloy containing $\mathrm{S}\left(\mathrm{Al}_{2} \mathrm{CuMg}\right)$ and $\theta^{\prime}\left(\mathrm{Al}_{2} \mathrm{Cu}\right)$ precipitates in 4.0\% NaCl solution at pH 6.1," Mater. Chem. Phys., 91, 325-329 (2005).

26. M. Jafari, M. H. Enayati, M. H. Abbasi, and F. Karimzadeh, "Thermal stability and structural changes during heat treatment of nanostructured A12024 alloy," J. Alloys Comp., 478, 260-264 (2009).

27. S. M. R. Mousavi Abarghouie and S. M. Seyed Reihani, "Aging behavior of a 2024 Al alloy-SiCp composite,” Mater. Des., 31, No. 5, 2368-2374 (2010).

28. Z. Liu, P. H. Chong, A. N. Butt, et al., "Corrosion mechanism of laser-melted AA2014 and AA2024 alloys," Appl. Surf. Sci., 247, 294-299 (2005).

29. M. Iannuzzi and G. S. Frankel, "Inhibition of aluminum alloy 2024 corrosion by vanadates: an in situ atomic force microscopy scratching investigation," Corrosion, 63, 672-688 (2007).

30. R. G. Buchheit, R. P. Grant, P. F. Hlava, et al., "Local dissolution phenomena associated with $\mathrm{S}$ phase $\left(\mathrm{Al}_{2} \mathrm{CuMg}\right)$ particles in aluminum alloy 2024-T3," $J$. Electrochem. Soc., 144, No. 8, 2621-2628 (1997).

31. Z. Huda, N. I. Taib, and T. Zaharine, "Characterization of 2024-T3: an aerospace aluminum alloy,” Mater. Chem. Phys., 113, 515-517 (2009). 